
\title{
25 Research Square \\ Reliability Framework for Characterizing Heat Wave and Cold Spell Events
}

\section{Research Article}

Keywords:

Posted Date: October 6th, 2021

DOl: https://doi.org/10.21203/rs.3.rs-684055/v2

License: (c) (i) This work is licensed under a Creative Commons Attribution 4.0 International License.

Read Full License

Version of Record: A version of this preprint was published at Natural Hazards on February 18th, 2022. See the published version at https://doi.org/10.1007/s11069-022-05236-8. 


\section{Abstract}

The full text of this preprint has been withdrawn by the authors due to author disagreement with the posting of the preprint. Therefore, the authors do not wish this work to be cited as a reference. Questions should be directed to the corresponding author.

\section{Full Text}

The authors have withdrawn this preprint from Research Square. 